\title{
Clinical Reasoning: A 30-year-old man with acute paraplegia and left foot gangrene
}

Vimal K. Paliwal, DM, Rohit Chhirolya, MD, Zafar Neyaz, MD, and Vikas Agarwal, DM

Neurology ${ }^{\circledR}$ 2018;90:e1355-e1359. doi:10.1212/WNL.0000000000005300

\section{Section 1}

A 30-year-old man presented with acute onset of lower back and leg pains followed by appearance of weakness in legs in December 2016. The weakness progressed over 1 hour to complete inability to move legs in the bed. He also developed incontinence of urine and stools. After 2 weeks of onset of weakness, he complained of black discoloration of his left toes (figure). There was no history of weakness of upper limb, zonesthesia, fever, joint disease, alopecia, photosensitivity, oral ulcers, cardiac disease, recent surgery, any malignancy, drugs abuse, sexual promiscuity, recent weight loss, or Raynaud phenomenon. He denied a history of diabetes mellitus or hypertension. He chewed tobacco chronically and occasionally consumed alcohol. He was not a vegetarian.

On examination of his feet, there was dry gangrene involving the pulp of his left toes. There was an area of cutaneous gangrene in the presacral region. The left dorsalis pedis and left posterior

\author{
Correspondence \\ Dr. Paliwal \\ dr_vimalkpaliwal@ \\ rediffmail.com
}

Figure Anterior spinal artery infarction and gangrene of left toes

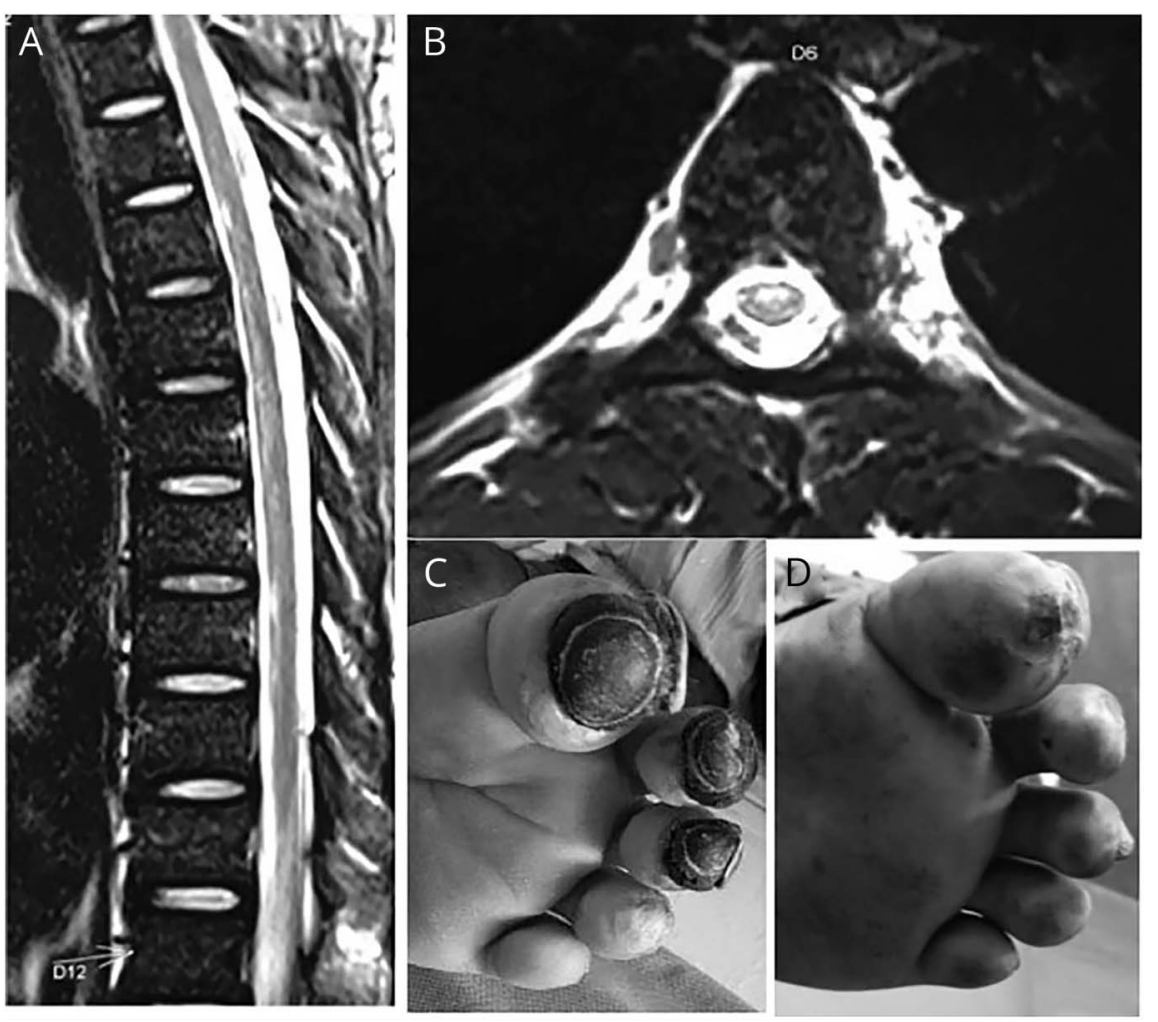

(A) MRI spine sagittal T2-weighted images show hyperintensity in the anterior spinal cord extending from D5 to D 12 levels. (B) T2 axial MRI at the level of D6 shows hyperintensity involving anterior part of spinal cord. (C) Gangrene of left toes that shows improvement (D) after 3 months of treatment.

From the Departments of Neurology (V.K.P., R.C.), Radiology (Z.N.), and Immunology (V.A.), SGPGIMS, Lucknow, India

Go to Neurology.org/N for full disclosures. Funding information and disclosures deemed relevant by the authors, if any, are provided at the end of the article. 
tibial artery were not palpable. All other peripheral pulsations were normal. His blood pressure in upper limbs and right lower limb was normal. His higher mental functions and examination of cranial nerves and upper limbs was normal. Neurologic examination of legs showed hypotonia, grade 0/5 power (Medical Research Council Grade), absent knee and ankle jerks, and nonelicitable planter responses. He had 80\% loss of pinprick sensations below the T3 spinal dermatome.
Posterior column sensations (fine touch, joint position sense and vibration) were normal. He had excessive sweating in the legs. There was no evidence of spinal deformity, tenderness, or bruit over his spine. His systemic examination was normal.

\section{Questions for consideration:}

1. What is the differential diagnosis of this condition?

2. What investigations would you perform? 


\section{Section 2}

The triad of motor weakness in the legs, sensory level in the trunk, and autonomic system dysfunction suggests the involvement of dorsal spinal cord. Areflexia and hypotonia in legs is secondary to spinal shock. Acute onset of paraplegia with sparing of posterior column sensations suggests an anterior spinal artery syndrome. The anterior spinal artery supplies the anterior two-thirds of the spinal cord that contains pyramidal tracts, spinothalamic tracts, and autonomic fibers. Therefore, the occlusion of anterior spinal artery produces acute paraplegia with impaired spinothalamic sensations and bowel-bladder dysfunction. The posterior column sensations are spared because paired posterior spinal arteries perfuse them. Other possibilities are infectious/parainfectious acute transverse myelitis, patchy myelitis secondary to multiple sclerosis, and nutritional/toxic myelopathy. Acute transverse myelitis seems an unlikely cause because it produces complete cord syndrome and does not spare posterior column sensations. Most parainfectious myelitis occurs after a preceding infection (flu-like illness or infective diarrhea) or vaccination. Our patient had a monophasic disease that goes against the possibility of multiple sclerosis. Most nutritional causes produce subacute onset of myelopathies and usually affect posterior column sensations. These myelopathies occur in people predisposed to nutritional deficiencies. Different toxic myelopathies have specific geographic predilections. In India, lathyrism, triorthocresyl phosphate, and fluorosis are prevalent in some states. These myelopathies are progressive pure motor syndromes. The constellation of anterior spinal artery syndrome and gangrene of the toes suggests an underlying vascular cause.

MRI of the spinal cord showed hyperintensity extending from D5 to D12 spinal segments that involved the anterior spinal cord regions on axial T2-weighted sequences (figure). The corresponding regions appeared hypointense on T1-weighted sequence. There was no evidence of contrast enhancement or any spinal arteriovenous malformation. MRI of brain including magnetic resonance angiography was normal.

\section{Questions for consideration:}

1. What are the causes of anterior spinal artery syndrome?

2. How would you approach a case of anterior spinal artery syndrome?

\section{GO TO SECTION 3}




\section{Section 3}

Common causes of anterior spinal artery infarction include aortic rupture, thrombosis or dissection, aortic aneurysm repair, hypotension, and spinal arteriovenous malformation. ${ }^{1}$ Other less common causes are anterior spinal artery embolism, collagen vascular disease, coagulation/hematologic disorders like sickle-cell disorder, polycythemia vera, paraproteinemias, and cryptogenic causes.

Our patient never had any aortic injury and he never required an aortic repair. His CT angiography showed normal aorta and renal vessels. He never had a hypotensive episode. MRI spine was negative for spinal arteriovenous malformation. Echocardiography results were normal. Blood investigations revealed erythrocyte sedimentation rate $140 \mathrm{~mm}$ first hour, serum protein $8.4 \mathrm{mg} / \mathrm{dL}$, and serum albumin $2.9 \mathrm{mg} / \mathrm{dL}$ suggesting a reversed albumin to globulin ratio. His 24-hour urinary albumin was $400 \mathrm{mg}$. His antinuclear antibodies, ds DNA, extractable nuclear antigen screen, and antiphospholipid antibody tests were negative. Tests for sickling, hemoglobin electrophoresis, paroxysmal nocturnal hemoglobinurea, protein $\mathrm{C}$ and $\mathrm{S}$, anti-thrombin III, factor V Leiden mutation, and hyperhomocysteinemia were negative.

We also evaluated causes of skin necrosis/gangrene. Many of them are discussed above. There are additional causes that can produce gangrene and can potentially produce anterior spinal artery thrombosis. They are disseminated intravascular coagulation, drug-induced (coumarin-induced) skin necrosis, calciphylaxis, cryoglobulinemia, cryofibrinogenemia, thrombotic thrombocytopenic purpura, and hemolytic uremic syndrome. ${ }^{2}$ Our patient had normal platelet count, no fibrinogen degradation products, and normal prothrombin time. His renal function was normal. His urine examination was negative for hemoglobinuria. He was never exposed to anticoagulants. However, his test for cryofibrinogenemia was positive (rated as heavy). Cryoglobulins were negative. Serum electrophoresis showed band in albumin, $\alpha 1, \alpha 2$, and $\beta$ region. No $M$-band was detected. His $\alpha 1$ antitrypsin levels were elevated but $\alpha 2$ macroglobulin levels were normal. He was diagnosed with essential cryofibrinogenemia.

\section{Questions for consideration:}

1. What is the treatment for essential cryofibrinogenemia?

2. What is the prognosis of essential cryofibrinogenemia?

\section{GO TO SECTION 4}




\section{Section 4}

By the time we received the patient's reports, his left popliteal artery pulsations had appeared. Therefore we did not offer him thrombolytic drugs. For persisting gangrene of his toes, we prescribed him anabolic steroids (stanozolol $4 \mathrm{mg}$ twice daily). He had received methylprednisolone $1 \mathrm{~g}$ daily for 5 days before visiting us. Gradually, he regained grade 3/5 to 4/ 5 power in different muscle groups of legs and started walking with support. His gangrene also improved over a period of 3 months (figure). His plasma cryofibrinogen was trace at 8 months.

Prognosis of cryofibrinogenemia is good. In a study of 60 patients with cryofibrinogenemia, $78 \%$ of patients showed complete remission. However, relapses were observed at a median interval of 9 months in nearly $50 \%$ of patients. The patients in this study received antithrombotic agents, steroids, and immunosuppressant drugs. ${ }^{3}$

\section{Discussion}

Cryofibrinogenemia refers to precipitation of proteins in the plasma when it is cooled to $4^{\circ} \mathrm{C}$. Similarly, precipitation of proteins in serum upon cooling is called cryoglobulinemia. Cryofibrinogenemia is seen in up to $7 \%$ of the healthy population and $10 \%-13 \%$ of the hospitalized population. However, when a cryopathy is suspected, cryofibrinogenemia can be seen in $12 \%-51 \%$ of patients. ${ }^{4}$ This suggests that despite high prevalence, cryofibrinogenemia is underrecognized. Cryofibrinogenemia can be primary (essential) or secondary (associated with an underlying disorder like malignancy, connective tissue disorder, vasculitis, sepsis, or associated with cryoglobulinemia). ${ }^{5}$ Skin manifestations are the most common presenting feature (purpura, urticaria, skin necrosis, livedo reticularis, Raynaud phenomenon, and gangrene) followed by fever, arthralgia, myalgia, multineuritis, and renal involvement. ${ }^{4}$ Thrombotic manifestation in cryofibrinogenemia varies widely from $0 \%$ to $55 \%$ of patients in different series. Arterial thrombosis may affect renal, aortic, iliac, femoral, retinal, and cerebral vessels. ${ }^{4}$ To our knowledge, anterior spinal artery thrombosis has not been reported with cryofibrinogenemia.

Cryofibrinogenemia can be diagnosed easily by simple laboratory testing. Testing is performed by centrifugation of plasma (and serum for cryoglobulins) at $37^{\circ} \mathrm{C}$, which is then cooled to $4^{\circ} \mathrm{C}$ and observed for $24-72$ hours. ${ }^{6}$ The cryoprecipitate that develops redissolves on warming the plasma and reprecipitates on cooling. The cryoprecipitate can be quantified by spectrophotometry but the measure usually remains imprecise. The contents of the cryoprecipitate can be determined by using immunofixation tests. The precipitant protein primarily consists of fibrin, fibronectin, and factor VIII. Pathophysiology of cryofibrinogenemia is not exactly known. Elevated antiportease-like $\alpha 1$ antitrypsin and $\alpha 2$ macroglobulin are antifibrinolytic and may result in accumulation of cryofibrinogen that clots with thrombin. Our patient had polyclonal bands in $\alpha 1$ and $\alpha 2$ region on serum protein electrophoresis. He had raised blood $\alpha 1$ antitrypsin levels.

Diagnosis of essential cryofibrinogenemia requires a compatible clinical presentation, demonstration of cryoprecipitate, absence of cryoglobulinemia, and exclusion of secondary causes of cryofibrinogenemia. Presence of elevated levels of $\alpha 1$ antitrypsin and $\alpha 2$ macroglobulin, pathologic evidence of cryoprecipitate clogging the arteries, and angiographic evidence of arterial occlusion are supportive criteria for the diagnosis of cryofibrinogenemia. ${ }^{5}$

Our patient responded well to stanozolol. Stanozolol is an androgenic steroid with inherent fibrinolysis-promoting activity. ${ }^{8}$ It may be used for maintenance therapy after initial thrombolytic drugs. Other treatments used are corticosteroids, immunosuppressants like azathioprine and cyclophosphamide, anticoagulants, and plasmapheresis. Long-term treatment and follow-up is essential because of recurrence of symptoms in high proportion of patients. Cryofibrinogenemia often occurs after cold exposure. Our patient developed symptoms in late December. Therefore, living in a warm environment is recommended to prevent recurrences.

\section{Author contributions}

Vimal Kumar Paliwal: conception and drafting of manuscript. Rohit Chhirolya: acquisition and analysis of clinical and electronic data. Zafar Neyaz: acquisition and analysis of radiologic data, drafting of manuscript. Vikas Agarwal: wrote figure legends and revised the manuscript.

\section{Study funding}

No targeted funding reported.

\section{Disclosure}

The authors report no disclosures relevant to the manuscript. Go to Neurology.org/N for full disclosures.

\section{References}

1. Cheshire WP, Santos CC, Massey EW, Howard JF. Spinal cord infarction: etiology and outcome. Neurology 1996;47:321-330.

2. James WD, Berger TG, Elston DM. Cutaneous vascular diseases. In: James WD, Berger TG, Elston DM, eds. Andrews' Diseases of the Skin: Clinical Dermatology, 12th ed. Philadelphia: Elsevier; 2016:807-855.

3. Saadoun D, Elalamy I, Ghillani-Dalbin P, Sene D, Delluc A, Cacoub P. Cryofibrinogenemia: new insights into clinical and pathogenic features. Am J Med 2009;122: $1128-1135$.

4. Michaud M, Pourrat J. Cryofibrinogenemia. J Clin Rheumatol 2013;19:142-148.

5. Amdo TD, Welker JA. An approach to the diagnosis and treatment of cryofibrinogenemia. Am J Med 2004;116:332-337.

6. Elizabeth M, Van Cott E, Laposata M. Coagulation. In: Jacobs DS, Oxley DK, DeMott WR, eds. The Laboratory Test Handbook, 5th ed. Cleveland: Lexi-Comp; 2001: 327-358.

7. Smith SB, Arkin C. Cryofibrinogenemia: incidence, clinical correlations, and a review of the literature. Am J Clin Pathol 1972;58:524-530.

8. Preston FE, Burakowski BK, Porters NR, Malia RG. The fibrinolytic response to stanozolol in normal subjects. Thromb Res 1981;22:543-551. 


\section{Neurology}

Clinical Reasoning: A 30-year-old man with acute paraplegia and left foot gangrene

Vimal K. Paliwal, Rohit Chhirolya, Zafar Neyaz, et al.

Neurology 2018;90;e1355-e1359

DOI 10.1212/WNL.0000000000005300

This information is current as of April 9, 2018

Updated Information \&

Services

References

Subspecialty Collections

Permissions \& Licensing

Reprints including high resolution figures, can be found at: http://n.neurology.org/content/90/15/e1355.full

This article cites 6 articles, 1 of which you can access for free at: http://n.neurology.org/content/90/15/e1355.full\#ref-list-1

This article, along with others on similar topics, appears in the following collection(s):

Hematologic

http://n.neurology.org/cgi/collection/hematologic

Spinal cord infarction

http://n.neurology.org/cgi/collection/spinal_cord_infarction

Information about reproducing this article in parts (figures,tables) or in its entirety can be found online at:

http://www.neurology.org/about/about_the_journal\#permissions

Information about ordering reprints can be found online:

http://n.neurology.org/subscribers/advertise

Neurology ${ }^{\circledR}$ is the official journal of the American Academy of Neurology. Published continuously since 1951, it is now a weekly with 48 issues per year. Copyright @ 2018 American Academy of Neurology. All rights reserved. Print ISSN: 0028-3878. Online ISSN: 1526-632X.

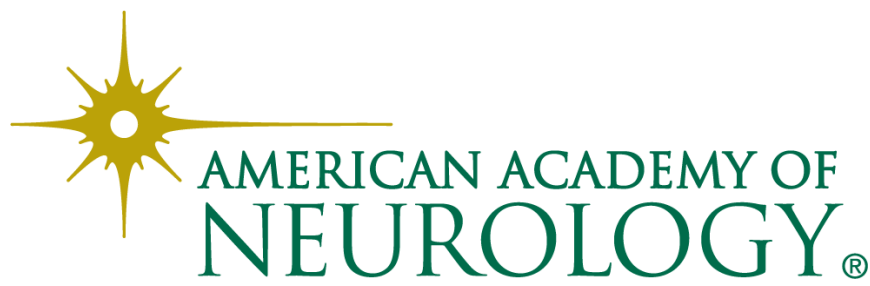

